\title{
Building Organisational Sustainability during the COVID-19 Pandemic with an Inspiring Work Environment
}

\author{
Maja Rožman ${ }^{1, *}$, Anita Peša ${ }^{2}\left(\right.$, Mladen Rajko $^{2}$ and Tjaša Štrukelj ${ }^{1}$ \\ 1 Faculty of Economics and Business, University of Maribor, 2000 Maribor, Slovenia; tjasa.strukelj@um.si \\ 2 Department of Economics, University of Zadar, 23000 Zadar, Croatia; apesa@unizd.hr (A.P.); \\ mrajko@unizd.hr (M.R.) \\ * Correspondence: maja.rozman1@um.si; Tel.: +386-2-22-90-291
}

check for updates

Citation: Rožman, M.; Peša, A.;

Rajko, M.; Štrukelj, T. Building

Organisational Sustainability during the COVID-19 Pandemic with an

Inspiring Work Environment.

Sustainability 2021, 13, 11747. https:/ /

doi.org/10.3390/su132111747

Academic Editor: Roope Husgafvel

Received: 16 September 2021

Accepted: 21 October 2021

Published: 25 October 2021

Publisher's Note: MDPI stays neutral with regard to jurisdictional claims in published maps and institutional affiliations.

Copyright: (C) 2021 by the authors Licensee MDPI, Basel, Switzerland. This article is an open access article distributed under the terms and conditions of the Creative Commons Attribution (CC BY) license (https:/ / creativecommons.org/licenses/by/ $4.0 /)$.

\begin{abstract}
This article aims to analyse significant differences in four constructs: occupational stress, job satisfaction, work engagement, and work productivity among employees before and after the COVID-19 pandemic. The purpose of the paper is to develop a multidimensional model with these four constructs and analyse the differences in the strength of their effects on the model across two intersectional times: before the COVID-19 pandemic and during the COVID-19 pandemic. The research was implemented on a sample of 885 employees in Slovenian organisations. During COVID19 , Slovenia had one of the strictest lockdowns. Based on the research, we can confirm significant differences in the four analysed constructs among employees before COVID-19 and during COVID19. Based on the results, we can confirm that occupational stress had a more negative effect on job satisfaction and work engagement during COVID-19 than before prior to it. Our research and conclusions highlight the measures with which organisations can reduce the problem of occupational stress and with which organisations can increase job satisfaction, work engagement and work productivity among employees during COVID-19. Based on this, organisations may be able to build a more supportive work environment during, and after, COVID-19.
\end{abstract}

Keywords: organisational sustainability; work environment; COVID-19; stress; satisfaction; engagement; productivity; wellbeing

\section{Introduction}

The COVID-19 pandemic has affected economies, societies and individuals in every way. The growing number of COVID-19 cases and deaths, lockdowns, substantial restrictions on public life and the economic crisis are likely to negatively impact personal wellbeing and mental health [1]. With the COVID-19 outbreak has come increased global business and economic disruption, as well as uncertainty. The COVID-19 pandemic is creating unfathomable loss and disruption. Business operations have been challenged with this new reality, and some have ground to a halt [2]. Due to the impact of social and business situations caused by the COVID-19 pandemic, a critical issue to consider is survival [3]. At this time, many organisations face significant challenges caused by the COVID-19 pandemic [4]. Due to social distancing and the adoption of lockdown measures to combat COVID-19, work from home is the new way to ensure business continuity [5].

The COVID-19 can have a strong psychological impact on individuals dealing with job uncertainty [6]. Lateef [6] states that new business strategies and the sudden encountering of life-altering changes can cause stress [6]. Remote working also has negative results, such as a reduced possibility of promotion, isolation, the breakdown of professional relationships, and an increase in family-work conflict, all of which may lead to lower work engagement and productivity $[7,8]$. On this basis, it is necessary to create a suitable work environment for employees [7]. Lee [9] emphasises that considering the current isolation, because of the COVID-19 pandemic, levels of stress and anxiety are growing. According to Jamal et al. [5], employees experience mental health issues. Also, stress is 
considered the silent enemy, which can trigger physiological and emotional problems [5]. Employees' emotional and mental health impact their productivity and satisfaction in the workplace [10]. High stress levels can be identified in times of crisis or adverse situations [3]. Castro de Araujo and Machado [10] mention a high impact on people's mental health may be due to high levels of uncertainty and the economic crisis. According to Singh [11], during the COVID-19 pandemic, many employees report that their work is a significant source of stress and anxiety that can quickly rise to an anxiety disorder with negative consequences for physical and mental health, wellbeing, and work engagement.

Governments in different countries around the world responded to COVID-19 by implementing a work-from-home policy to reduce transmission of the virus from one person to another [7]. Additionally, Madell [12] argued that work-from-home has disadvantages as it does not offer a physical separation between work and private time and that, in the end, home may be a boring work environment [12]. These disadvantages lead to a low level of satisfaction and can also lead to a lower level of work engagement. Consequently, a low level of work engagement leads to decreased productivity among employees (see, e.g., $[3,5,7,12-14])$. On the other hand, the authors $[2,10]$ report that some employees have more time for themselves and find it easier to reconcile their work and private lives, which, in turn, increases their job satisfaction and work productivity. In general, employee performance plays a crucial role in the success of an organisation [15]. The work-from-home discussion is always related to electronic communication [16], and employees may not get recognition and support when needed, which may lead to their dissatisfaction [17]. The downside of working from home is also that some employees may work overtime, but their work is only judged by the result, not by the difficulties that employees overcame during the process $[18,19]$. The latest change related to the work-from-home policy during COVID-19 is in work-life balance. Zhang [16] emphasises that family problems can negatively impact employees' moods at work when everything happens at the same time and place. All this is reflected in lower work engagement which leads to lower productivity of employees.

According to Pedraza et al. [1], employees report lower dissatisfaction and anxiety during COVID-19. Changes in the workplace due to COVID-19, such as a decrease in income or an increase or decrease in workload, are associated with more significant anxiety and dissatisfaction [1]. This situation requires academic research to provide organisations with the right strategies to face the challenges of the COVID-19 pandemic [20]. Therefore, the paper aims to test if there are significant differences in occupational stress, job satisfaction, work productivity and work engagement among employees before and during the COVID-19 pandemic. Also, the paper aims to highlight which problems of occupational stress, job satisfaction, work productivity and work engagement are faced by employees during the COVID-19 pandemic. Even though some studies have revealed positive or negative results during COVID-19, we wanted to analyse the situation in Slovenia. From this point of view, we used the items used by the authors in their research and based on the results in our research, we wanted to determine whether employees are more or less productive, engaged, or satisfied during COVID-19. The paper aims to develop a multidimensional model with these four constructs to analyse them before and during the COVID-19 pandemic. Furthermore, we will analyse the differences in strength of the effects of these constructs along two intersectional times (before the COVID-19 pandemic and during the COVID-19 pandemic). Our research highlights how organisations can reduce the problem of occupational stress and shows tools for organisations with which they can increase job satisfaction, work productivity and work engagement among employees during the COVID-19 epidemic.

\section{Literature Review and Hypotheses}

\subsection{Occupational Stress during COVID-19}

Occupational stress has a negative impact on employees' performance, irrespective of the organisation and type of employment [21]. Occupational stress negatively affects 
employee health, which leads to a lack of motivation and satisfaction, absenteeism, low productivity, a low instinct to perform, fatigue, and less interest in work [22,23]. According to Toscano and Zappalà [7], in remote work during the COVID-19 pandemic, the social isolation generated by the lack of face-to-face contact with colleagues is positively associated with stress. Sahni [19] emphasises that the current situation with lockdown and work from home during the COVID-19 become stressful for many employees. Primary stress in the workplace for employees during COVID-19 comes from work-family imbalances, high workloads with unrealistic deadlines, and job insecurity, all of which lead to a lower level of work engagement among employees [19].

Moreover, Goddard et al. [24] found increased levels of stress in those employees who worked from home during COVID-19 because they may feel isolated and anxious, and may worry about reductions in hours and lack of long term prospects. On the other hand, employees may be less prone to stress if they work from home, as they find it easier to reconcile their professional and private lives $[1,20]$. Therefore, we hypothesise that (Figure 1):

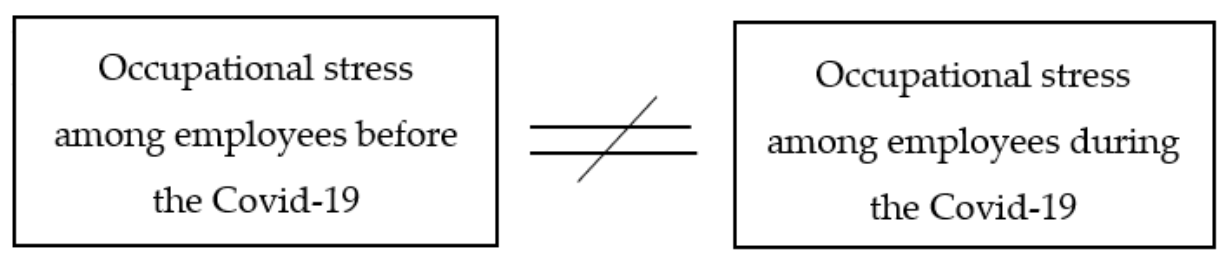

Figure 1. Significant differences for Hypothesis 1 (H1).

Hypothesis 1 (H1). There are significant occupational stress differences among employees before COVID-19 and during COVID-19.

\subsection{Job Satisfaction during COVID-19}

Many countries set up lockdowns to attempt to contain COVID-19 [25]. All people operating in non-essential positions of employment were ordered to stay at home, allowing only a tiny percentage of employees in essential services (e.g., food, healthcare, delivery) to go to work $[25,26]$. Due to the closure of schools, children's learning moved online, and parents who work from home have had to look after their children during working hours, leading to a lower job satisfaction [26]. Given the closure of schools, day-care centres and the restriction of house visits by nurses and nannies, the situation has been made even more tough for working parents, who have also had to take care of their children while performing daily work tasks. For affected families, parental burnout is an ordinary outcome arising from the need to manage the time commitment and logistics of distance learning and home schooling [27], leading to lower job satisfaction [19,26]. COVID-19 can upend employees' ability to balance their office work and household work, leading to lower job satisfaction. Given that COVID-19 is unlikely to be contained soon, working from home or partial work from home (hybrid-office) is likely to become a new norm for many organisations [28]. Therefore, we hypothesise that (Figure 2):

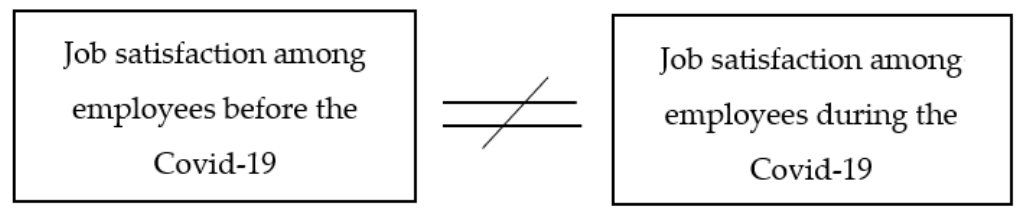

Figure 2. Significant differences for Hypothesis $2(\mathrm{H} 2)$.

Hypothesis 2 (H2). There are significant job satisfaction differences among employees before COVID-19 and during COVID-19. 


\subsection{Work Engagement during COVID-19}

The negative influence of COVID-19 on the working and personal lives of employees may lead to frustration, anxiety, stress and burnout. Moreover, these negative feelings can affect employees' work engagement, leading to work errors and poor work quality which may eventually influence an organisation's ability to survive in these difficult times [29]. Due to lockdown, work from home is difficult for employees as they do not feel the organisational climate at home. Due to frequent interruptions of family members, work-life conflict arises. Also, some employees at home do not have the proper equipment and tools (computer, mouse, printers, scanners, headphones, webcam, internet connection, and dedicated workspace- a quiet place to work). They are not certain about their job security or about their salary [14,29]. During the pandemic, most employees feel stressed and depressed. Because of these problems, employees may lose focus on their work, so there is a need for more employee engagement [14]. Therefore, we hypothesise that (Figure 3):

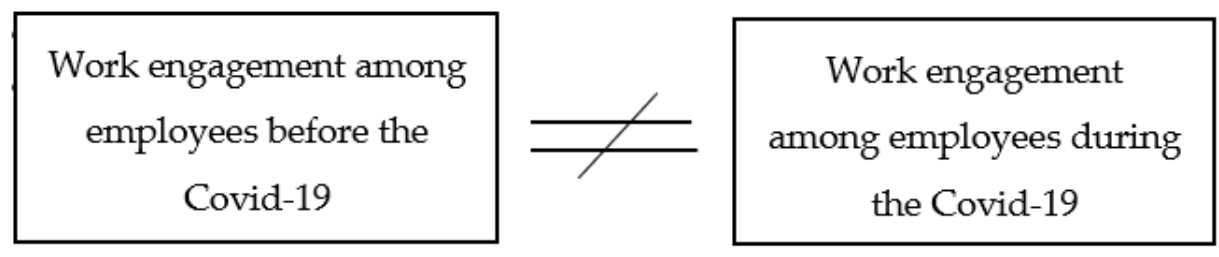

Figure 3. Significant differences for Hypothesis $3(\mathrm{H} 3)$.

Hypothesis 3 (H3). There are significant work engagement differences among employees before COVID-19 and during COVID-19.

\subsection{Employee Productivity during COVID-19}

During COVID-19, stress and isolation are negatively related to the perception of remote work productivity [7]. Thus, remote employees are spending time in more meetings, are working longer, and keeping up with more communication channels, leading to higher stress and less productivity [30]. Employees that work from home during the pandemic have reported high stress and adverse mental health. Employees may develop a range of behavioural reactions (e.g., consequences on performance), physical reactions (e.g., headache, gastric disturbances), and psychological reactions (e.g., mood swings, lowered motivation, depressive thoughts, and isolation) [7,30,31]. Combined with the closure of public spaces, schools and day-cares, this has left many employees newly working from home and facing new stresses, additional responsibilities at home, and a fading work-life balance that decreases their work productivity [31]. On the other hand, for employees who work individually and are able to regulate work obligations and working hours, productivity has not decreased [2,9]. Therefore, we hypothesise that (Figure 4):

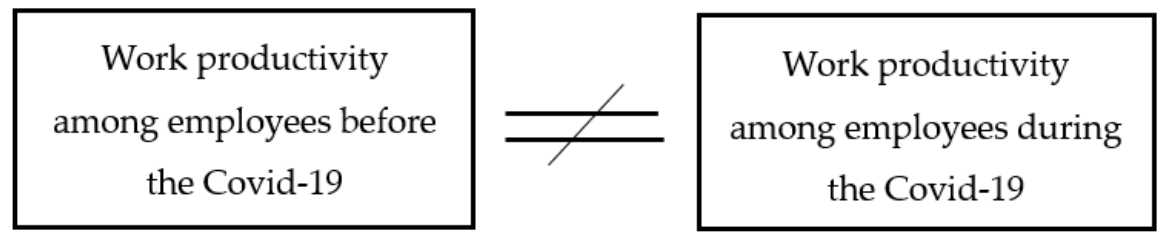

Figure 4. Significant differences for Hypothesis 4 (H4).

Hypothesis 4 (H4). There are significant work productivity differences among employees before COVID-19 and during COVID-19. 
2.5. The Conceptual Model of Research Relating to Differences in the Strength of the Effects among Constructs during the COVID-19 Pandemic

Garg et al. [32] found a positive effect between work engagement and job satisfaction among employees. Results show that job satisfaction leads to higher work engagement [32]. During COVID-19, employees face lower satisfaction, which leads to a lower level of work engagement [7]. For most of them, a change of environment was the biggest challenge, going from the office-where everyone is among colleagues in work-mode, to home-where varying contrasts abound (such as being alone, having young children at hand or elderly relatives to care for, or even a neighbouring baby or pet making noise), all of which would be disruptive to any workflow [2,5]. A high level of occupational stress leads to lower job satisfaction and lower work engagement [19]. On the other hand, employees who can balance their work and home responsibilities during COVID-19 reported lower stress and a higher level of job satisfaction, which, in turn, also leads to more outstanding work engagement [32]. Additionally, employees who are well engaged in an organisation will lead to productivity in their place of work, and this generates higher customer satisfaction and, ultimately, developments in sales and profit for the organisation [14]. Work engagement is a crucial element of employee and organisation success. It predicts employee performance, organisational success, and the financial performance of the organisation. The impact of employee engagement or disengagement manifests in the productivity of the organisation [33]. During the pandemic, employees face high occupational stress [24], which leads to low job satisfaction [26] and also a low level of work engagement during COVID-19 [14]. According to Kamal et al. [31] and Toscano and Zappalà [7], during COVID-19, employees have been less satisfied, leading to lower engagement and therefore lower productivity. On that basis, we want to examine if there are any differences in the strength of the effects among constructs in the conceptual model between employees in two intersectional times before and during the COVID-19 pandemic. Therefore, we developed a conceptual model and the following hypothesis with four sub-hypotheses (Figure 5):

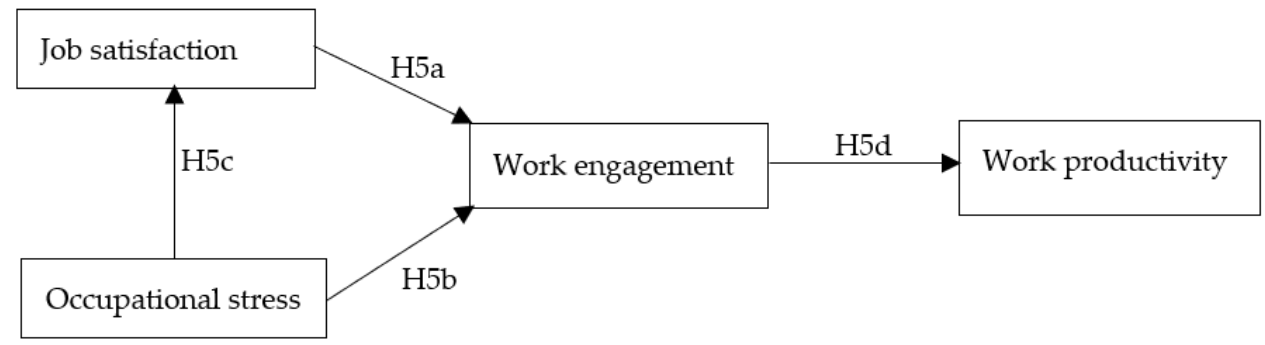

Figure 5. Conceptual model of research.

Hypothesis 5 (H5). There are significant differences in the strength of the effects among constructs in the model between employees in two intersectional times-before COVID-19 and during COVID-19.

Hypothesis 5a (H5a). Job satisfaction has a less positive effect on work engagement during COVID-19 than before COVID-19.

Hypothesis $\mathbf{5 b} \mathbf{( H 5 b ) . ~ O c c u p a t i o n a l ~ s t r e s s ~ h a s ~ a ~ m o r e ~ n e g a t i v e ~ e f f e c t ~ o n ~ w o r k ~ e n g a g e m e n t ~ d u r i n g ~}$ COVID-19 than before COVID-19.

Hypothesis 5c (H5c). Occupational stress has a more negative effect on job satisfaction during COVID-19 than before COVID-19.

Hypothesis $\mathbf{5 d}(\mathbf{H} 5 \mathbf{d})$. Work engagement has a less positive direct effect on work productivity during COVID-19 than before COVID-19. 
According to the above hypothesis and sub-hypotheses, the conceptual model presented in Figure 5 was proposed.

\section{Materials and Methods}

\subsection{Participants and Procedure}

Our research includes two samples of employees before COVID-19 (885 employees) and during COVID-19 (885 employees).

The research, conducted from January to March 2021, involved 177 Slovenian organisations, and five employees from each organisation participated in our research. Thus, 885 employees responded to the survey form, a questionnaire.

The first data group was gained from April 2019 to July 2019 as part of broader research, and in this part, we used the same measuring instrument.

In the research during COVID-19, the percentage of employees aged from 26 to 31 years was $11.0 \%$, the percentage of employees aged from 32 to 37 years was $13.2 \%$, the percentage of employees aged from 38 to 43 years was $16.0 \%$, the percentage of employees aged from 44 to 49 was $21.4 \%$, the percentage of employees aged from 50 to 55 years was $25.4 \%$ and the percentage of employees aged from 56 to 61 years was $7.6 \%$. The percentage of employees aged over 62 years was $5.4 \%$. Medium-sized organisations presented $40.7 \%$ of employees, large organisations presented $35.6 \%$ of employees, and small organisations presented $23.7 \%$ of employees. The organisations researched were from manufacturing $(22.0 \%)$; trade, maintenance, and the repair of motor vehicles $(16.4 \%)$; financial and insurance activities (14.1\%); information and communication activities (10.3\%); professional, scientific and technical activities (10.7\%); real estate business $(12.4 \%)$; other diversified business activities (7.3\%); catering $(2.8 \%)$; transport and storage $(2.3 \%)$; and construction $(1.7 \%)$.

In the research before COVID-19, the percentage of employees aged from 26 to 31 years was $12.7 \%$, the percentage of employees aged from 32 to 37 years was $17.6 \%$, the percentage of employees aged from 38 to 43 years was $19.8 \%$, the percentage of employees aged from 44 to 49 years was $21.5 \%$, the percentage of employees aged from 50 to 55 was $17.6 \%$, the percentage of employees aged from 56 to 61 years was $7.1 \%$, and the percentage of employees aged over 62 years was $3.7 \%$. The percentage employed in medium-sized organisations was $38.4 \%$, followed by large $(36.2 \%)$ and small $(25.4 \%)$. The organisations in which employees are employed were from manufacturing (13.5\%); trade, maintenance, and the repair of motor vehicles (18.0\%); professional, scientific and technical activities $(12.4 \%)$; financial and insurance activities (11.8\%); information and communication activities (11.2\%); other diversified business activities (10.6\%); catering $(10.2 \%)$; construction (7.2\%); and transport and storage (5.1\%).

\subsection{Measures}

A closed-type questionnaire was used in the research instrument. Items for occupational stress were adopted from Mosadeghrad [22]; items for job satisfaction were adopted from Hayday [34]; items for work engagement were adopted from Robinson et al. [35] and Gallup [36]; items for work productivity were adopted from Putri et al. [37]. The questionnaire used a 5-point Likert-type scale.

\subsection{Data Analysis}

In the beginning, we analysed differences in the level of individual items about each construct (occupational stress, work engagement, job satisfaction and work productivity) among employees before and during complete lockdown conditions during COVID-19. The data are not normally distributed for all individual items in each construct, shown by the Kolmogorov-Smirnov and Shapiro-Wilk tests [38]. Based on this, the non-parametric Mann-Whitney $U$ test for two independent samples was used. Also, we used descriptive statistics to show the average rate for each item and calculated the standard deviation. 
In the second step, structural equation modelling (SEM) with PLS-SEM was used. Confirmatory factor analysis was used to (1) test the dimensionality of constructs and (2) establish convergent and discriminant validity. The reliability of measurement scales was assessed within the scope of inner consistency with Cronbach's alpha coefficient $[39,40]$. For testing reliability, the composite reliability (CR) measure was used. Also, for testing convergent validity, the average variance extracted (AVE) was used. Discriminant validity was assessed with Fornell and Larcker [41] criterion by comparing the square root of AVE to all correlation coefficients. Standardised root mean square residual (SRMR) fit and normed fit (NFI) indices were used to assess the fit of the measurement model.

\section{Results}

4.1. Descriptive Statistics and Significant Differences in Constructs before and during the COVID-19 Pandemic

As mentioned above, we used the non-parametric Mann-Whitney $U$ test because the data for all items that describe occupational stress, job satisfaction, work engagement and work productivity are not normally distributed. Tables $1-4$ show descriptive statistics and significant differences in each of the four constructs' items among employees before and during COVID-19.

Table 1. Descriptive statistics and significant occupational stress differences among employees before and during COVID-19.

\begin{tabular}{|c|c|c|c|c|c|c|}
\hline \multirow[b]{2}{*}{ Item } & \multicolumn{2}{|c|}{ Before COVID-19 } & \multicolumn{2}{|c|}{ During COVID-19 } & \multirow[b]{2}{*}{ Mann-Whitney U } & \multirow{2}{*}{$\begin{array}{l}\text { Asymp. Sig. } \\
\text { (2-Tailed) }\end{array}$} \\
\hline & Mean & $\begin{array}{c}\text { Standard } \\
\text { Deviation }\end{array}$ & Mean & $\begin{array}{c}\text { Standard } \\
\text { Deviation }\end{array}$ & & \\
\hline $\begin{array}{l}\text { I am facing stress in performing work } \\
\text { tasks (Q1a). }\end{array}$ & 3.60 & 0.850 & 3.95 & 0.924 & $329,829.000$ & 0.000 \\
\hline $\begin{array}{l}\text { Due to stress in the workplace, I feel a } \\
\text { lack of energy, tiredness (Q1b). }\end{array}$ & 3.17 & 1.004 & 3.83 & 1.171 & $270,865.000$ & 0.000 \\
\hline $\begin{array}{l}\text { Due to stress in the workplace, I have } \\
\text { problems with concentration (Q1c). }\end{array}$ & 2.55 & 0.966 & 3.66 & 1.395 & $240,632.000$ & 0.000 \\
\hline I'm irritable (Q1d). & 2.65 & 1.036 & 3.64 & 1.396 & $642,992.000$ & 0.000 \\
\hline $\begin{array}{l}\text { Due to stress in the workplace, I have } \\
\text { headaches, migraines (Q1e). }\end{array}$ & 3.27 & 1.138 & 3.80 & 1.232 & $291,981.000$ & 0.000 \\
\hline My sleep cycle is messy (Q1f). & 3.53 & 1.095 & 3.86 & 1.138 & $316,535.500$ & 0.000 \\
\hline $\begin{array}{l}\text { At the workplace, the stance of my body } \\
\text { is forced for a long time (for example, } \\
\text { sitting); therefore, I have lower back pain, } \\
\text { shoulder pain (Q1g) }\end{array}$ & 3.56 & 1.120 & 3.93 & 1.168 & $295,807.000$ & 0.000 \\
\hline I have depressed feelings (Q1h). & 2.34 & 1.020 & 3.74 & 1.553 & $202,342.500$ & 0.000 \\
\hline I'm tense $(\mathrm{Q} 1 \mathrm{i})$ & 3.32 & 1.051 & 3.71 & 1.143 & $326,108.000$ & 0.000 \\
\hline I feel panic (Q1j). & 2.25 & 0.952 & 3.68 & 1.563 & $214,761.500$ & 0.000 \\
\hline $\begin{array}{l}\text { I am afraid of losing the job or not } \\
\text { finishing the work on a schedule (Q1k). }\end{array}$ & 2.78 & 1.105 & 3.88 & 1.327 & $212,855.000$ & 0.000 \\
\hline I am emotionally exhausted (Q11). & 2.57 & 1.106 & 3.78 & 1.428 & $218,895.000$ & 0.000 \\
\hline I have insomnia (Q1m). & 3.51 & 1.073 & 3.85 & 1.122 & $302,187.500$ & 0.000 \\
\hline
\end{tabular}


Table 2. Descriptive statistics and significant job satisfaction differences among employees before and during the COVID-19 pandemic.

\begin{tabular}{|c|c|c|c|c|c|c|}
\hline \multirow[b]{2}{*}{ Item } & \multicolumn{2}{|c|}{ Before COVID-19 } & \multicolumn{2}{|c|}{ During COVID-19 } & \multirow[b]{2}{*}{ Mann-Whitney U } & \multirow{2}{*}{$\begin{array}{l}\text { Asymp. Sig. } \\
\text { (2-Tailed) }\end{array}$} \\
\hline & Mean & $\begin{array}{l}\text { Standard } \\
\text { Deviation }\end{array}$ & Mean & $\begin{array}{l}\text { Standard } \\
\text { Deviation }\end{array}$ & & \\
\hline $\begin{array}{l}\text { I am satisfied with the working hours and } \\
\text { distribution of work obligations (Q2a). }\end{array}$ & 3.71 & 1.088 & 3.37 & 1.022 & $321,262.500$ & 0.000 \\
\hline $\begin{array}{l}\text { I am satisfied with flexible working hours } \\
\qquad(\mathrm{Q} 2 \mathrm{~b}) .\end{array}$ & 3.76 & 1.066 & 3.36 & 0.982 & $307,048.000$ & 0.000 \\
\hline $\begin{array}{l}\text { I am satisfied with the balance between } \\
\text { my work and private life (Q2c). }\end{array}$ & 3.73 & 1.052 & 3.48 & 0.974 & $362,427.500$ & 0.005 \\
\hline $\begin{array}{c}\text { I am satisfied with the level of } \\
\text { self-regulation of work speed that is } \\
\text { enabled (Q2d). }\end{array}$ & 3.75 & 1.064 & 3.44 & 0.977 & $326,284.000$ & 0.000 \\
\hline $\begin{array}{l}\text { I am satisfied with the number of } \\
\text { education, training programs (Q2e). }\end{array}$ & 3.56 & 1.246 & 3.21 & 1.204 & $333,530.000$ & 0.000 \\
\hline $\begin{array}{l}\text { I am satisfied with enabling the flexible } \\
\text { workspace (for example, working from } \\
\text { home) (Q2f). }\end{array}$ & 3.04 & 1.109 & 3.65 & 1.210 & $308,890.500$ & 0.000 \\
\hline $\begin{array}{c}\text { I am satisfied with the leadership in the } \\
\text { organisation }(\mathrm{Q} 2 \mathrm{~g}) \text {. }\end{array}$ & 3.79 & 1.130 & 3.68 & 1.194 & $370,490.000$ & 0.048 \\
\hline
\end{tabular}

Table 3. Descriptive statistics and significant work engagement differences among employees before and during the COVID-19 pandemic.

\begin{tabular}{|c|c|c|c|c|c|c|}
\hline \multirow[b]{2}{*}{ Item } & \multicolumn{2}{|c|}{ Before COVID-19 } & \multicolumn{2}{|c|}{ During COVID-19 } & \multirow[b]{2}{*}{ Mann-Whitney U } & \multirow{2}{*}{$\begin{array}{l}\text { Asymp. Sig. } \\
\text { (2-Tailed) }\end{array}$} \\
\hline & Mean & $\begin{array}{l}\text { Standard } \\
\text { Deviation }\end{array}$ & Mean & $\begin{array}{l}\text { Standard } \\
\text { Deviation }\end{array}$ & & \\
\hline I do my work with passion (Q3a). & 3.83 & 1.024 & 3.48 & 1.189 & $347,369.000$ & 0.000 \\
\hline $\begin{array}{l}\text { I am engaged in the quality of my work } \\
\text { (Q3b). }\end{array}$ & 4.17 & 0.793 & 3.69 & 1.468 & $360,667.000$ & 0.002 \\
\hline $\begin{array}{l}\text { I am engaged in achieving successful } \\
\text { business results (Q3c). }\end{array}$ & 4.12 & 0.859 & 3.42 & 1.663 & $333,820.000$ & 0.000 \\
\hline $\begin{array}{l}\text { I am aware of the importance of } \\
\text { innovation for our organisation, and I am } \\
\text { helping to develop the organisation } \\
\text { (Q3d). }\end{array}$ & 3.97 & 0.930 & 3.38 & 1.596 & $342,104.000$ & 0.000 \\
\hline $\begin{array}{l}\text { I feel that my work and job are important } \\
\qquad(\mathrm{Q} 3 \mathrm{e}) .\end{array}$ & 3.94 & 1.032 & 3.61 & 1.343 & $344,971.000$ & 0.000 \\
\hline $\begin{array}{l}\text { I am proud to be employed in this } \\
\text { organisation (Q3f). }\end{array}$ & 3.80 & 1.025 & 3.65 & 1.380 & $362,993.500$ & 0.009 \\
\hline $\begin{array}{l}\text { I believe in the successful development } \\
\text { and operation of our organisation (Q3g). }\end{array}$ & 4.02 & 0.932 & 3.67 & 1.387 & $351,802.500$ & 0.000 \\
\hline I feel excellent at my workplace (Q3h). & 3.73 & 1.269 & 3.36 & 1.270 & $330,381.500$ & 0.000 \\
\hline
\end{tabular}


Table 4. Descriptive statistics and significant work productivity differences among employees before and during the COVID-19 pandemic.

\begin{tabular}{|c|c|c|c|c|c|c|}
\hline \multirow[b]{2}{*}{ Item } & \multicolumn{2}{|c|}{ Before COVID-19 } & \multicolumn{2}{|c|}{ During COVID-19 } & \multirow[b]{2}{*}{ Mann-Whitney U } & \multirow{2}{*}{$\begin{array}{l}\text { Asymp. Sig. } \\
\text { (2-Tailed) }\end{array}$} \\
\hline & Mean & $\begin{array}{l}\text { Standard } \\
\text { Deviation }\end{array}$ & Mean & $\begin{array}{l}\text { Standard } \\
\text { Deviation }\end{array}$ & & \\
\hline $\begin{array}{l}\text { I do not feel a reduction in my capacity to } \\
\text { perform work tasks (Q4a). }\end{array}$ & 4.17 & 1.319 & 3.15 & 1.471 & $247,885.500$ & 0.000 \\
\hline $\begin{array}{l}\text { I do not feel a lack of my ability to } \\
\text { perform work }(\mathrm{Q} 4 \mathrm{~b})\end{array}$ & 4.32 & 1.209 & 3.11 & 1.373 & $206,660.500$ & 0.000 \\
\hline $\begin{array}{l}\text { My willingness to work has not } \\
\text { diminished (Q4c). }\end{array}$ & 4.23 & 1.269 & 3.08 & 1.373 & $217,133.000$ & 0.000 \\
\hline $\begin{array}{l}\text { The quality of my work has not } \\
\text { diminished (Q4d). }\end{array}$ & 4.42 & 1.165 & 3.19 & 3.703 & $214,478.000$ & 0.000 \\
\hline $\begin{array}{l}\text { The quantity of my work done within a } \\
\text { specific time frame has not decreased } \\
(\mathrm{Q} 4 \mathrm{e}) .\end{array}$ & 4.27 & 1.262 & 3.12 & 1.394 & $215,114.000$ & 0.000 \\
\hline $\begin{array}{l}\text { My focus on achieving successful work } \\
\text { results has not diminished (Q4f). }\end{array}$ & 4.38 & 1.194 & 2.92 & 1.388 & $184,435.000$ & 0.000 \\
\hline $\begin{array}{l}\text { My accuracy at work has not decreased } \\
\qquad(\mathrm{Q} 4 \mathrm{~g}) .\end{array}$ & 4.40 & 1.209 & 3.22 & 1.493 & $229,696.500$ & 0.000 \\
\hline I feel excellent at my workplace (Q3h). & 3.73 & 1.269 & 3.36 & 1.270 & $330,381.500$ & 0.000 \\
\hline
\end{tabular}

The results (Table 1) show that, on average, occupational stress among employees during the pandemic is perceived to be higher than occupational stress among employees before COVID-19 pandemic. Table 1 demonstrates that the means for answers about the occupational stress among employees during COVID-19 indicate that, on average, employees had the highest agreement with; facing stress in performing work tasks (mean: 3.95); increased lower back and shoulder pain (mean: 3.93); fear of losing their job or not finishing their work on a schedule (mean: 3.88); messy sleep cycle (mean: 3.86); insomnia (mean: 3.85); lack of energy, tiredness (mean: 3.83); headaches, migraines (mean: 3.80); emotional exhaustion (mean: 3.78); depressed feelings (3.74); and tension (3.71). On the other hand, the result outcomes indicate that employees before the COVID-19 pandemic on average agree with the statement about facing stress in performing work tasks (mean: 3.60). Still, the average agreement is much lower than that of employees during COVID-19 (mean: 3.95). Also, the results indicate that employees before the COVID-19 pandemic, on average, agreed with statements about messy sleep cycle (3.53) and insomnia (3.51). Still, the average agreement is much lower as compared with employees during COVID-19. Also, Table 1 shows that employees before COVID-19, on average, neither agreed nor disagreed with all other statements. Based on the research results of the non-parametric Mann-Whitney U test $(p<0.05)$, we confirmed Hypothesis 1 (H1: There are significant occupational stress differences among employees before COVID-19 and during COVID-19). Table 2 presents descriptive statistics and significant job satisfaction differences among employees before and during COVID-19.

The results (Table 2) show that, on average, the job satisfaction among employees during COVID-19 was perceived to be lower than job satisfaction among employees before COVID-19. Table 2 shows the means for answers regarding job satisfaction among employees during the COVID-19 pandemic, which indicate that, on average, employees had lower agreement with all statements as compared with employees before COVID19 , except with satisfaction with enabling the flexible workspace (for example, working from home). During COVID-19, employees had the highest agreement with satisfaction with the leadership in the organisation (mean: 3.68) and satisfaction with enabling a flexible workspace (for example, working from home). The results indicate that employees 
during the COVID-19 pandemic on average neither agreed nor disagreed with all other statements and disagreed about satisfaction with the number of education and training programmes. Also, results indicate that employees before the COVID-19 pandemic on average agreed with all statements, except where they neither agreed nor disagreed about their satisfaction with enabling a flexible workspace (for example, working from home). Employees before the COVID-19 pandemic were, on average, the most satisfied with leadership in their organisation (mean: 3.79), which is the same as during COVID-19. Therefore, we found that employees were satisfied with leadership in both time periods (but the average agreement rate is lower during COVID-19). Based on the research results of the non-parametric Mann-Whitney U test $(p<0.05)$, we confirmed Hypothesis 2 (H2: There are significant job satisfaction differences among employees before COVID-19 and during COVID-19). Table 3 presents descriptive statistics and significant work engagement differences among employees before and during the COVID-19 pandemic.

The results show (Table 3 ) that, on average, work engagement among employees during the COVID-19 pandemic is perceived to be lower than work engagement among employees before the COVID-19 pandemic. Table 3 shows the means for answers regarding work engagement among employees during the COVID-19 pandemic, which indicate that, on average, employees had a lower agreement with all statements than employees before COVID-19. During COVID-19 employees had the highest agreement with their engagement to the quality of work (mean: 3.69), which is the same as before COVID19, but the average of the agreement was higher (mean: 4.17). Also, employees during COVID-19 on average agree with the statements in which they believe in the successful development and operation of their organisation (mean: 3.67), are proud to be employed in their organisation (mean: 3.65), and feel that their work and job are important (mean: 3.61); however, the average of these agreements are lower as compared with employees before COVID-19. Also, results show that employees during COVID-19 on average neither agreed nor disagreed with doing work with passion (mean: 3.48), being engaged to achieve successful business results (mean: 3.42), having an awareness of the importance of innovation for organisation, helping to develop the organisation (mean: 3.38) and feeling very good at their workplace (mean: 3.36). Based on the research results of the non-parametric Mann-Whitney U test $(p<0.05)$, we confirmed Hypothesis 3 (H3: There are significant work engagement differences among employees before COVID-19 and during COVID-19). Table 4 presents descriptive statistics and statistically significant work productivity differences among employees before and during the COVID-19 pandemic.

The results (Table 4) show that, on average, work productivity among employees during COVID-19 is perceived as lower than work productivity among employees before COVID-19. Table 4 shows the means for answers about work productivity among employees during the COVID-19 pandemic, which indicate that, on average, employees had a lower agreement with all statements than employees before COVID-19. Also, results show that employees during COVID-19 on average neither agreed nor disagreed with all statements. On the other hand, employees before COVID-19 had highest agreement with asserting that the quality of work has not diminished (mean: 4.42), the accuracy at work has not decreased (mean: 4.40), and the focus on achieving successful work results has not diminished (mean: 3.38). Based on the research results of the non-parametric Mann-Whitney U test $(p<0.05)$, we confirmed Hypothesis 4 (H4: There are significant work productivity differences among employees before COVID-19 and during COVID-19).

\subsection{Structural Equation Modelling with PLS-SEM}

\subsubsection{Dimensionality, Validity, and Reliability}

First, the measurement model was assessed. Psychometric properties of these scales were assessed via evaluation of reliability, discriminant validity and convergent validity of each measurement scale. Fornell and Larcker's [41] assessment criteria were adopted for convergent validity. All item factor loadings should be significant and should exceed 0.70 , and the average variance extracted (AVE) for each construct should exceed $0.50[42,43]$. 
Table 5 shows item factor loadings for the four constructs, and Table 6 shows the constructs' reliability and validity.

Table 5. Item factor loadings for four constructs.

\begin{tabular}{|c|c|c|c|}
\hline \multirow{2}{*}{ Construct } & \multirow{2}{*}{ Items } & Before COVID-19 & During COVID-19 \\
\hline & & Loadings & Loadings \\
\hline \multirow{13}{*}{ Occupational stress } & Q1a & 0.785 & 0.762 \\
\hline & Q1b & 0.840 & 0.771 \\
\hline & Q1c & 0.806 & 0.764 \\
\hline & Q1d & 0.808 & 0.715 \\
\hline & Q1e & 0.732 & 0.724 \\
\hline & Q1f & 0.760 & 0.737 \\
\hline & Q1g & 0.779 & 0.762 \\
\hline & Q1h & 0.834 & 0.813 \\
\hline & Q1i & 0.766 & 0.753 \\
\hline & Q1j & 0.792 & 0.769 \\
\hline & Q1k & 0.812 & 0.794 \\
\hline & Q11 & 0.825 & 0.789 \\
\hline & Q1m & 0.784 & 0.809 \\
\hline \multirow{7}{*}{ Job satisfaction } & Q2a & 0.814 & 0.885 \\
\hline & Q2b & 0.799 & 0.896 \\
\hline & Q2c & 0.748 & 0.897 \\
\hline & Q2d & 0.806 & 0.879 \\
\hline & Q2e & 0.769 & 0.863 \\
\hline & Q2f & 0.773 & 0.782 \\
\hline & Q2g & 0.818 & 0.805 \\
\hline \multirow{8}{*}{ Work engagement } & Q3a & 0.734 & 0.877 \\
\hline & Q3b & 0.788 & 0.814 \\
\hline & Q3c & 0.796 & 0.765 \\
\hline & Q3d & 0.804 & 0.792 \\
\hline & Q3e & 0.776 & 0.768 \\
\hline & Q3f & 0.733 & 0.804 \\
\hline & Q3g & 0.815 & 0.813 \\
\hline & Q3h & 0.786 & 0.775 \\
\hline \multirow{7}{*}{ Work productivity } & Q4a & 0.970 & 0.857 \\
\hline & Q4b & 0.959 & 0.871 \\
\hline & Q4c & 0.957 & 0.925 \\
\hline & Q4d & 0.889 & 0.913 \\
\hline & Q4e & 0.948 & 0.902 \\
\hline & Q4f & 0.905 & 0.934 \\
\hline & Q4g & 0.903 & 0.829 \\
\hline
\end{tabular}


Table 6. Constructs' reliability and validity.

\begin{tabular}{ccccccc}
\hline \multirow{2}{*}{ Construct } & \multicolumn{3}{c}{ Before COVID-19 } & \multicolumn{3}{c}{ During COVID-19 } \\
\cline { 2 - 7 } & Cronbach's Alpha & AVE & CR & Cronbach's Alpha & AVE & CR \\
\hline Job satisfaction & 0.886 & 0.637 & 0.912 & 0.929 & 0.716 & 0.945 \\
\hline Occupational stress & 0.951 & 0.630 & 0.956 & 0.968 & 0.604 & 0.811 \\
\hline Work engagement & 0.967 & 0.857 & 0.973 & 0.975 & 0.983 & 0.998 \\
\hline Work productivity & 0.973 & 0.877 & 0.977 & 0.920 & 0.712 & 0.940 \\
\hline
\end{tabular}

In Table 5, all individual item factor loadings were higher than the recommended level of 0.70 and significant $(p<0.001)$. Also, all AVE values exceeded 0.50 (Table 6$)$. The remainder of our measurement scales show strong evidence for convergent validity.

The reliability of measurement scales was assessed within the scope of inner consistency with Cronbach's alpha coefficient [40,44]. Within convergent validity, we examined composite reliability coefficients (CR > 0.7) and average variance extracted (AVE > 0.5) and the criterion CR > AVE [45]. According to Kock [45], each construct average variance extracted (AVE) should exceed 0.50 .

Results of Cronbach's alphas (Table 6) indicate that the scales were reliable for all scales across two samples (before and during COVID-19). Composite reliabilities (CR) for all four constructs are more significant than 0.7. The average variance extracted (AVE) values for all four constructs are more significant than 0.5 . We confirmed the convergent validity for all the constructs studied because all $C R$ values were higher than AVE values.

The results of the correlation matrix in Table 7 show that the discriminate validity of all scales is also adequate (square root AVE exceed non-diagonals elements in the same row or columns).

Table 7. Correlation matrix among the latent variables and square roots of the AVE.

\begin{tabular}{|c|c|c|c|c|c|}
\hline & Constructs & Work Engagement & Work Productivity & Job Satisfaction & Occupational Stress \\
\hline \multirow{5}{*}{ Before COVID-19 } & Work engagement & $0.902 *$ & & & \\
\hline & Work productivity & 0.267 & $0.859 *$ & & \\
\hline & Job satisfaction & 0.433 & 0.223 & $0.876^{*}$ & \\
\hline & Occupational stress & -0.454 & -0.317 & -0.615 & $0.885^{*}$ \\
\hline & & Work Engagement & Work Productivity & Job Satisfaction & Occupational Stress \\
\hline \multirow{4}{*}{ During COVID-19 } & Work engagement & $0.873 *$ & & & \\
\hline & Work productivity & 0.248 & $0.839 *$ & & \\
\hline & Job satisfaction & 0.397 & 0.307 & $0.846^{*}$ & \\
\hline & Occupational stress & -0.208 & -0.361 & -0.539 & $0.862 *$ \\
\hline
\end{tabular}

Results (Table 7) show that Fornell and Larcker's [41] criterion was achieved in all cases. Thus, all square roots of AVE were higher than the latent variable correlations.

\subsubsection{PLS-SEM Results}

Structural path coefficients were analysed using the significance level at 0.05 . $R$ square $\left(R^{2}\right)$ and adjusted $R$ square (Adjusted $R^{2}$ ) were used to measure the total magnitude of the effect size for the structural equation model (SEM) [46]. Table 8 show the goodness of fit for the structural model.

Results in Table 8 show that $R^{2}$ values for all endogenous variables (work engagement, work productivity, job satisfaction) were higher than 0.4. Table 9 shows the fit indices for PLS-SEM where the NFI and the SRMR index were used. The model adaptation was assessed by the standardised root mean square residual (SRMS). Henseler et al. [47] 
introduce the SRMR as a goodness of fit measure for PLS-SEM that can be used to avoid model misspecification [47]. The model fits well when SRMS is lower than 0.10 [43]. According to $\mathrm{Hu}$ and Bentler [48], a value less than 0.10 or 0.08 is considered a good fit. Also, a model is regarded as acceptable if the normed fit index (NFI) exceeds 0.90 [49]. Table 9 shows the fit indices for PLS-SEM.

Table 8. The goodness of fit for the structural model.

\begin{tabular}{ccccc}
\hline \multirow{2}{*}{ Constructs } & \multicolumn{2}{c}{ Before COVID-19 } & \multicolumn{2}{c}{ During COVID-19 } \\
\cline { 2 - 5 } & $\mathbf{R}^{\mathbf{2}}$ & Adj. $\mathbf{R}^{\mathbf{2}}$ & $\mathbf{R}^{\mathbf{2}}$ & Adj. $\mathbf{R}^{\mathbf{2}}$ \\
\hline Occupational stress & & & & \\
\hline Work engagement & 0.609 & 0.591 & 0.528 & 0.501 \\
\hline Work productivity & 0.535 & 0.510 & 0.423 & 0.402 \\
\hline Job satisfaction & 0.567 & 0.558 & 0.489 & 0.481 \\
\hline
\end{tabular}

Table 9. Fit indices for PLS-SEM.

\begin{tabular}{ccc}
\hline & Before COVID-19 & During COVID-19 \\
\hline NFI & 0.926 & 0.915 \\
SRMR & 0.076 & 0.071 \\
\hline
\end{tabular}

Results in Table 9 show that NFI and SRMR criteria were achieved in both cases (before and during the COVID-19). NFI in both cases exceeds 0.90 (NFI in the model before COVID-19 is 0.926, and NFI in the model during COVID-19 is 0.915). Also, SRMR in both cases is less than 0.08 (SRMR in the model before COVID-19 is 0.076, and SRMR in the model during COVID-19 is 0.071).

Statistically significant relationships among the constructs were tested for Hypothesis $\mathrm{H} 5$ and sub-hypotheses H5a, H5b, H5c, H5d for employees' work environment assessment before COVID-19 and during COVID-19. Table 10, Figure 6, and Figure 7 show the statistically significant relationships among the constructs in two periods-before and during COVID-19.

Table 10. Standardised regression paths.

\begin{tabular}{|c|c|c|c|c|c|c|c|c|}
\hline \multirow{3}{*}{$\begin{array}{c}\text { Hypothesis } \\
\text { Period }\end{array}$} & \multirow{2}{*}{\multicolumn{2}{|c|}{$\begin{array}{c}\text { H5a } \\
\begin{array}{c}\text { Occupational Stress -> } \\
\text { Job Satisfaction }\end{array}\end{array}$}} & \multirow{2}{*}{\multicolumn{2}{|c|}{$\begin{array}{c}\text { H5b } \\
\text { Occupational Stress -> } \\
\text { Work Engagement }\end{array}$}} & \multirow{2}{*}{\multicolumn{2}{|c|}{$\begin{array}{c}\text { H5c } \\
\text { Job satisfaction }->\text { Work } \\
\text { Engagement }\end{array}$}} & \multirow{2}{*}{\multicolumn{2}{|c|}{$\begin{array}{c}\text { H5d } \\
\text { Work Engagement -> } \\
\text { Work Productivity }\end{array}$}} \\
\hline & & & & & & & & \\
\hline & $\begin{array}{c}\text { Before } \\
\text { COVID-19 }\end{array}$ & $\begin{array}{c}\text { During } \\
\text { COVID-19 }\end{array}$ & $\begin{array}{c}\text { Before } \\
\text { COVID-19 }\end{array}$ & $\begin{array}{c}\text { During } \\
\text { COVID-19 }\end{array}$ & $\begin{array}{c}\text { Before } \\
\text { COVID-19 }\end{array}$ & $\begin{array}{c}\text { During } \\
\text { COVID-19 }\end{array}$ & $\begin{array}{c}\text { Before } \\
\text { COVID-19 }\end{array}$ & $\begin{array}{c}\text { During } \\
\text { COVID-19 }\end{array}$ \\
\hline $\begin{array}{l}\text { Standardised } \\
\text { regression } \\
\text { paths }(\beta)\end{array}$ & $-0.489 *$ & $-0.678 *$ & $-0.443 *$ & $-0.602 *$ & 0.695 * & 0.412 * & 0.681 * & 0.423 * \\
\hline
\end{tabular}

Note: ${ }^{*} p<0.01$.

As can be observed from Table 10, Figures 6 and 7, the results show that occupational stress has a more negative effect on work engagement during the COVID-19 pandemic as compared with before the COVID-19 pandemic (before COVID-19: $\beta=-0.443, p<0.01$; during COVID-19: $\beta=-0.602, p<0.01$ ). Additionally, occupational stress has a more negative effect on job satisfaction during the COVID-19 pandemic as compared with before the COVID-19 pandemic (before COVID-19: $\beta=-0.489, p<0.01$; during COVID-19: $\beta=-0.678, p<0.01)$. The results show that job satisfaction has a less positive effect on work engagement during COVID-19 than before the COVID-19 pandemic (before COVID-19: $\beta=0.695, p<0.01$; during COVID-19: $\beta=0.412, p<0.01$ ). Also, the results show that work 
engagement has a less positive direct effect on work productivity during COVID-19 than before the COVID-19 pandemic (before COVID-19: $\beta=0.681, p<0.01$; during COVID-19: $\beta=0.423, p<0.01)$. During COVID-19, the relationship between the constructs of job satisfaction, work engagement and work productivity was much weaker and statistically significant. Also, during COVID-19, the effects between the constructs of occupational stress, work engagement, occupational stress, and job satisfaction were much stronger, more negative, and statistically significant. The effects in all cases during COVID-19 and before COVID-19 are statistically significant $(p<0.01)$. Therefore, we confirmed Hypothesis H5: There are differences in the strength of the effects among constructs in the model between employees in two intersectional times-before COVID-19 and during COVID-19. Thus, sub-hypotheses H5a-H5d are also confirmed.

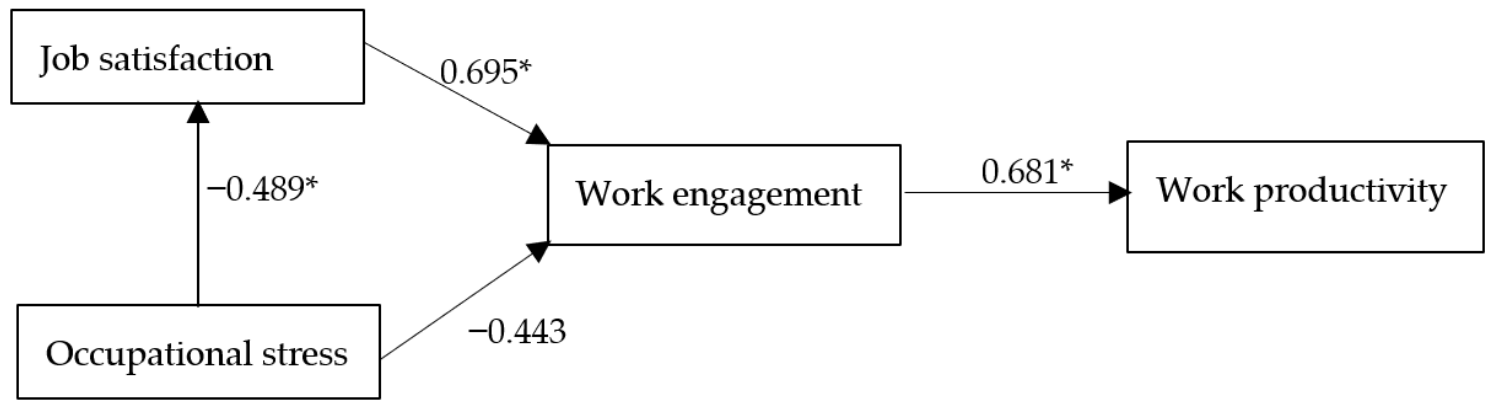

Figure 6. Results of structural model analysis for employees' work environment assessment before COVID-19. Note: ${ }^{*} p<0.01$.

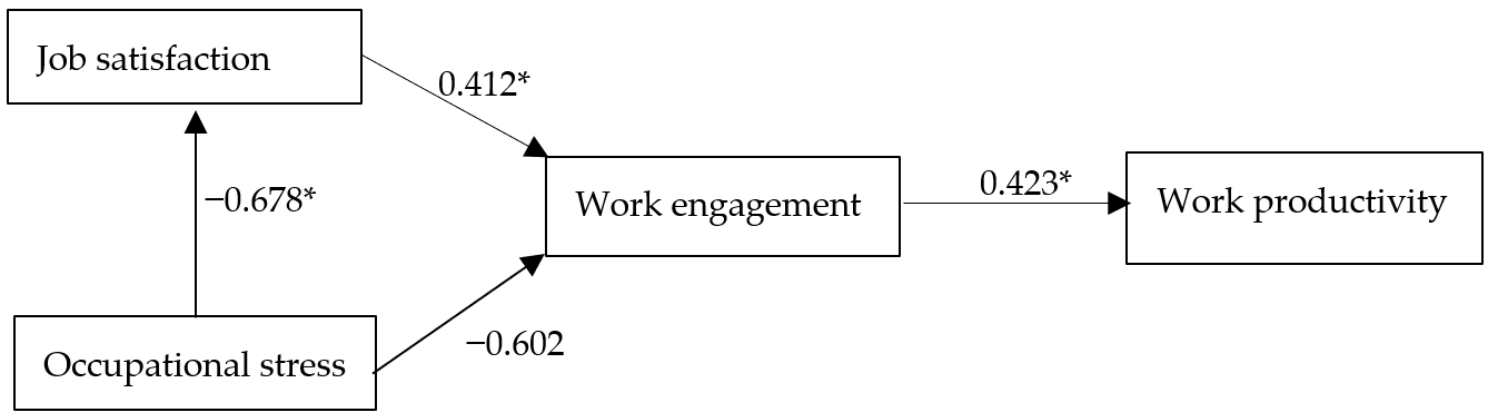

Figure 7. Results of structural model analysis for employees' work environment assessment during COVID-19. Note: ${ }^{*} p<0.01$.

\section{Discussion}

Liguori and Pittz [50] emphasise that new strategies are needed for a business to survive and thrive in the era of COVID-19. According to Chanana and Sangeeta [14], satisfied, engaged, and productive employees have become essential in today's pandemic situation [14]. Results show that occupational stress has a more negative effect on work engagement during COVID-19 than before the COVID-19 pandemic. Occupational stress has a more negative effect on job satisfaction during COVID-19 than before the COVID-19 pandemic. Also, based on the results, we concluded that job satisfaction has a less positive effect on work engagement during COVID-19 than before COVID-19. Also, work engagement has a less positive direct effect on work productivity during COVID-19 than before COVID-19.

Based on the results, we found significant differences in occupational stress, job satisfaction, work productivity and work engagement among employees before and during COVID-19. In addition, results show differences in the strength of the effects among constructs in the conceptual model between employees in two intersectional times-before COVID-19 and during COVID-19. We found that occupational stress has a more negative effect on work engagement during COVID-19 than before COVID-19. Occupational stress 
has a more negative effect on job satisfaction during COVID-19 as compared with before COVID-19. Also, results show that job satisfaction has a less positive effect on work engagement during COVID-19 than before COVID-19. Work engagement has a less positive direct effect on work productivity during COVID-19 than before COVID-19.

Due to economic inactivity and business closures, many employers have changed their business strategies or reduced their workforce. Therefore, employees must deal with higher stress than before COVID-19. Based on the results, we found that the occupational stress among employees during COVID-19 is perceived higher than occupational stress among employees before the pandemic. In addition, based on the results, we found that there are statistically significant occupational stress differences among employees before the COVID-19 pandemic and during COVID-19, which is in line with [7,19,24,51,52]. The results indicate that employees during the COVID-19 pandemic face higher stress in performing work tasks, suffering from back pain, shoulder pain, fear of losing their job or not finishing the work on schedule, messy sleep cycle, insomnia, lack of energy, tiredness, headaches, migraines, emotional exhaustion, depression, tension, panic, problems with concentration and irritability. On the other hand, the results show that employees before the COVID-19 pandemic, on average, agree with the statement about messy sleep cycles and insomnia. However, the average agreement is much lower than with employees during COVID-19. The results indicate that employees before the COVID-19 pandemic on average neither agreed nor disagreed with all other statements. However, employees during COVID-19 agree with all statements about occupational stress. Also, results show that occupational stress has a more negative effect on work engagement during the COVID19 compared with before the COVID-19 pandemic. Occupational stress has a more negative effect on job satisfaction during COVID-19 as compared with before COVID-19. This is a severe indication that organisations need to act and build organisational sustainability with a more supportive work environment during COVID-19.

According to Gavidia's research [51], employees reported that the COVID-19 pandemic was the most stressful time, associated with a marked increase in insomnia, anxiety and antidepressant medications. According to Ginger's survey [52], American employees were stressed before COVID-19, but during COVID-19 stress levels are through the roof. Before the onset of COVID-19, almost $60 \%$ of employees shared that stress had brought them to tears at work, representing a 23\% increase from 2019. During COVID-19, employees' stress levels were reported to be significantly higher: $88 \%$ of employees described experiencing moderate to extreme stress during the past $4-6$ weeks; $69 \%$ of employees described this as the most stressful period of their entire professional career, including major events like the September 11 terror attacks, the 2008 Great Recession and others. Every demographic, including adults over 55, rated COVID-19 as the most stressful time; $91 \%$ of employees working from home reported experiencing moderate to extreme stress; $43 \%$ of employees have become physically ill due to work-related stress [52]. Also, Kumar et al. [53] and Abbas and Zhiqiang [54] found that during COVID-19, employees report losing job satisfaction and work engagement which is reflected in low productivity. Therefore, employees need to adopt the following strategies to reduce occupational stress.

Employers should support open communication and provide clarity to employees on all work-related issues, including the tools needed to perform their tasks. In fact, poor communication increases stress in the workplace. Employers can also organise regular online meetings to allow employees to discuss how the pandemic affects work and what changes could help them better cope with new job requirements. Employers should intensively support flexibility at work. Especially in this tough period during COVID-19, employees need flexibility at work more than ever. Concerned about exposing themselves to infection in the workplace, the organisation could introduce a hybrid work pattern so that employees go to offices only a few days a week. Also, working parents are under a lot of stress, as some schools and kindergartens are closed, meaning that employees will need more flexibility at work to have better control between work and private life. Employers should help employees manage stress through various online courses on overcoming stress 
during COVID-19 or a video teleconference with mental health professionals. Employers could also develop a stress management policy that clearly describes employees' steps when they experience signs of stress in the workplace. The suggested measures may reduce the negative impact of occupational stress on employees' social isolation, performance, motivation, satisfaction, absenteeism, productivity, and interest in work [7,21-23].

Based on the results, we found that job satisfaction among employees during COVID19 is perceived lower than job satisfaction among employees before COVID-19. Also, there are statistically significant job satisfaction differences among employees before and during COVID-19, which is in line with $[26,27,55,56]$. The results indicate that employees during the COVID-19 pandemic on average neither agreed nor disagreed with the statements regarding satisfaction with the number of education and training programmes, flexible working hours, working hours and distribution of work obligations, the level of self-regulation of work speed that is enabled, and the balance between their work and private life. Employees during COVID-19, on average, agree with statements regarding satisfaction with leadership in the organisation and with enabling a flexible workspace (e.g., working from home). However, their average agreement is much lower as compared with the time before COVID-19. On the other hand, employees before COVID-19 agree with all statements about job satisfaction, except with satisfaction with enabling a flexible workspace (for example, working from home). In contrast, employees during COVID-19 are satisfied with enabling a flexible workspace (for example, working from home). Also, the results show that job satisfaction has a less positive effect on work engagement during COVID-19 than before the COVID-19 pandemic. During COVID-19, the flexibility of teleworking has increased, enabling work from home, but this also leads to other work-related dissatisfactions. Closing schools and kindergartens will force many working parents to supervise or run home-schooling. Compliance with these requirements is complex for many parents, especially those who must continue to work $[57,58]$. Moreover, this leads to lower job satisfaction and work engagement during COVID-19 [56]. Thus, job satisfaction has a less positive effect on work engagement during COVID-19 than before COVID-19 [55].

Therefore, employers need to recognise signs of distress among their employees, directly through interviews and indirectly through observation. Open and two-way communication with an employee provides the information they need and enables the expression of negative emotions and the improvement of feelings of control. The employer should adjust work obligations to those employees who educate their children at home and grant them more flexible work arrangements. Flexible work systems give employees the freedom to perform their work duties and tasks. Also, employees should organise further education and training programs during COVID-19 because the new work model calls for new tools and resources to meet new work requirements. Employers should also provide their employees with training opportunities through online seminars, online courses, and other channels to help them advance in their tasks and goals. For example, employers should provide employees with the right technology and resources to make the process easy for employees who are just getting into the swing of remote work. Employers should provide information about, and access to, ergonomic workstations to ensure employees are at their best when working. The suggested measures may reduce the negative impact of the closure of non-essential services, day-cares and schools, of children's online learning, and other working from home challenges on employees' ability to balance their household work and office work, preventing burnout and thus raising their job satisfaction $[19,26,27]$.

Based on the results, we found that work engagement among employees during COVID-19 is perceived lower than work engagement among employees before the COVID19 pandemic. In addition, based on the results, we found statistically significant work engagement differences among employees before and during COVID-19, which is in line with [29] and [14]. The results indicate that employees during COVID-19 had the highest agreement with the statement regarding engagement to the quality of work, similarly to before COVID-19, though the average was higher before COVID-19. Also, results show that employees during COVID-19 on average neither agreed nor disagreed with statements 
regarding doing work with passion, their engagement to achieve successful business results, being aware of the importance of innovation for their organisation, helping to develop the organisation and feeling very good at the workplace. In the time before COVID-19, employees were engaged with all characteristics that describe work engagement (doing work with passion, being engaged to the quality of work, being engaged in achieving successful business results, being aware of the importance of innovation for the organisation and helping to develop the organisation, having a feeling that their work and job are important, being proud to be employed in the organisation, believing in the successful development and operation of the organisation, feeling very good at their workplace). Also, results show that work engagement has a less positive direct effect on work productivity during COVID-19 than before COVID-19.

Clear goals and regular communication in these difficult times will help employees maintain focus, a sense of purpose, mental wellbeing and energy. Although employees may become more risk-averse in this uncertain environment, these times of significant change are crucial for employee engagement and organisational success. Even if an organisation has limitations on new investments during COVID-19, employers can emphasise the need for innovations or processes, leading to employee engagement. Employers should also pay attention to the unique needs of employees. For example, those who face occupational stress should be provided with the necessary assistance. Times have changed, so work needs to be redesigned to adapt to changing times. One of the keys to maintaining employment during a health crisis is flexibility at work. An employer can also increase the engagement of their employees by giving employees free days to take care of their family during COVID-19. The COVID-19 pandemic has pushed employers to remodel work to fit into the changing environment. Employers need to pivot workplace strategies to safeguard employee health during the pandemic and enhance engagement and productivity in these unrivalled times. The suggested measures may improve employees' working and personal lives and decrease employees' work-life conflict, work errors, poor work quality, frustration, anxiety, stress, and burnout, thus reducing the negative impact of COVID-19 on employees' work engagement [14,29].

Based on results, we found that work productivity among employees during COVID19 is perceived lower than work productivity among employees before the COVID-19 pandemic. In addition, based on the results, we found statistically significant work productivity differences among employees before and during the COVID-19 pandemic, which is in line with $[7,31]$. Also, the results indicate that employees during COVID-19 have lower productivity than employees before COVID-19. They, on average, neither agreed nor disagreed with the characteristics that describes work productivity: a focus on achieving successful work results has not diminished, willingness to work has not diminished, not feeling a lack of ability to perform work, the quantity of work done within a specific time frame has not decreased, do not feel a reduction in capacity to perform work tasks, the quality of work has not diminished, and accuracy at work has not decreased. When we compared the average value with employees' statements before COVID-19, we found that employees before COVID-19 agree with all the characteristics that describe work productivity. Based on the outcome results, we found that employees before COVID-19 were much more productive.

Therefore, organisations must focus on employee emotions associated with COVID-19 to restore productivity and provide employee experience. The negative effect of the COVID19 pandemic on the personal and working lives of employees leads to stress, frustration, and burnout of employees. Thus, these negative feelings can impact employee productivity and engagement, leading to poor quality work, mistakes and eventually affecting an organisation's ability to survive these difficult times. Therefore, flexible working conditions, an influential work culture, and support from employers are some of the prerequisites for successful functioning. Employers need to help employees stay productive and connected with the organisation. The employer should know what motivates employees and what changes they want. Thus, an employer should open communication channels between 
themselves and their employees and create a safe environment for open feedback and the transfer of ideas (virtual meets). Open communication, employer support, and flexible working hours are prerequisites for ensuring employees' productivity and business success. The suggested measures may reduce the negative impact of the closure of public spaces, schools and day-cares; of stress and isolation; of numerous and time-consuming meetings, longer working hours, and increased challenges in communication; and of other behavioural, physical, and psychological reactions on employees' productivity $[7,30,31]$.

The confirmed hypotheses are clearly shown in Table 11.

Table 11. Assessed and confirmed hypotheses.

\begin{tabular}{cc}
\multicolumn{1}{c}{ Hypotheses } & Confirmation \\
\hline $\begin{array}{l}\text { H1: There are statistically significant occupational stress differences } \\
\text { among employees before COVID-19 and during COVID-19. }\end{array}$ & $\checkmark$ \\
\hline $\begin{array}{l}\text { H2: There are statistically significant differences in job satisfaction } \\
\text { among employees before COVID-19 and during COVID-19. }\end{array}$ & $\checkmark$ \\
\hline $\begin{array}{l}\text { H3: There are statistically significant differences in work engagement } \\
\text { among employees before COVID-19 and during COVID-19. }\end{array}$ & $\checkmark$ \\
\hline $\begin{array}{l}\text { H4: There are statistically significant work productivity differences } \\
\text { among employees before COVID-19 and during COVID-19. }\end{array}$ & $\checkmark$ \\
\hline $\begin{array}{l}\text { H5: There are differences in the strength of the relationships among } \\
\text { constructs in the conceptual model between employees in two } \\
\text { intersectional times-before COVID-19 and during COVID-19. }\end{array}$ & $\checkmark$ \\
\hline $\begin{array}{l}\text { H5a: Job satisfaction has a less positive effect on work engagement } \\
\text { during COVID-19 than before COVID-19. }\end{array}$ & $\checkmark$ \\
\hline $\begin{array}{l}\text { H5b: Occupational stress has a more negative effect on work } \\
\text { engagement during COVID-19 than before COVID-19. }\end{array}$ \\
\hline $\begin{array}{l}\text { H5c: Occupational stress has a more negative effect on job } \\
\text { satisfaction during COVID-19 than before COVID-19. }\end{array}$ \\
\hline $\begin{array}{l}\text { H5d: Work engagement has a less positive direct effect on work } \\
\text { productivity during COVID-19 than before COVID-19. }\end{array}$ \\
\hline
\end{tabular}

\section{Conclusions}

Organisations should be aware that engaged and productive employees are the key to organisational success in this challenging time. Therefore, organisations should look forward to keeping their employees satisfied through the engagement of employees during COVID-19.

Employees are the face of an organisation. Even a tiny change in the working process interrupts working speed, and it could be either an external or internal change. While small scale changes are easy to understand and move on from, a circumstance like COVID-19, which is developing every day, needs a lot of adjustment and planning to manage newer ways of working. Employees make a vital contribution to the success and competitiveness of the organisation. Organisations increasingly need to adapt to the market and increase their competitiveness. The situation with COVID-19 requires a lot of planning and adjustment and a new way of working. Our findings highlight the need for organisations to be aware of the extent and factors associated with occupational stress, work engagement, job satisfaction and work productivity among employees during COVID-19. Our research shows significant differences in occupational stress, job satisfaction, work engagement and work productivity among employees before and during COVID-19. Also, our research highlights the problems that are faced by employees for each construct separately. In addition, our research highlights differences in the strength of the effects among constructs in the multidimensional model between employees in two intersectional times-before and during the COVID-19 pandemic. We clearly presented how organisations can reduce 
the problem related to the studied constructs among employees during the COVID-19 pandemic. Our conclusion will help employers or managers create an appropriate and pleasant work environment for employees during COVID-19 and after the pandemic. In addition, our research and conclusions will help organisations develop new ways of working, with high levels of engagement and productivity with a more supportive work environment during COVID-19.

In these difficult times, the main aim of an organisation is to ensure a healthy life and promote general wellbeing at all stages of the lives of their employees. Teleworking turned out to be much more strenuous at the beginning of the pandemic than anyone would have imagined, especially from a psychological point of view. Suddenly we were torn away from our teams and often the workday was dragged on all day, thus a lot of people felt they were working even harder than usual. Therefore, we show that it is personally important for each individual to be aware of this situation and to consciously provide enough rest and support to/from other members of the team of his/her organisation. Everyone must recognise the changed conditions and be aware that they can be managed in a targeted way. Personal orientation towards sustainable development influences the sustainability of an organisation and through it the sustainability of the whole society. Therefore, we as individuals must first begin to pursue this goal in focus.

Advocating for the physical and mental health of employees has become even more important during the pandemic. Thus, organisations are already rapidly adapting workplaces in order to achieve hygiene and safety standards, establishing ways to work from home, establishing virtual tools for collaboration, and inventing new ways and tools to monitor and control work. This leads to an increase in work engagement, work satisfaction and work productivity which is especially important during the pandemic. For successful work, it is necessary to ensure an organisational culture based on trust, empathy, and transparency, while also considering different value orientations, motivational factors, and personality profiles of employees. When organisations promote sustainable development, they not only care about the wellbeing of employees but through their sustainable oriented operations contribute more to the wellbeing of the whole society (i.e., social responsibility), nature as such (i.e., responsibility to nature) and also to the profitability of the organisation (i.e., responsibility to shareholders in the form of profit).

We also draw the attention of economic policy makers to the aspects studied in this research. The state is interested in the wellbeing and health of the working population, as it improves its competitive position in the global market. Also, working people do not use health and other social benefits, which reduces the pressure on the state treasury. Therefore, it might make sense for states, similar to introducing mandatory reporting on the non-financial activities of organisations, to introduce mandatory reporting on health care (and thus stress reduction) and employee wellbeing. Namely, healthy employees are more satisfied with their work, more engaged in work, and thus more productive in their work. Higher productivity affects the organisation's performance and consequently enables a richer and more competitive state. Responsible behaviour of individuals, organisations and states is of key importance for all stakeholders, and the state, through its activity and encouragement to socially responsible behaviour (of individuals, organizations), also takes care of its otherwise better functioning. We suggest all proposed actions to be monitored and for further research we recommend the measurement of their effects at the personal level, at the level of organisations and at the level of individual states; later we also recommend making international comparisons. We are aware that we should establish and develop a research network for international comparisons, which is a particularly important challenge for human future operations if we, as humanity, decide to do so.

The limitation of this research is that it is limited to a reflection of employees in Slovenian organisations. Also, in our research, we were limited to four constructs: occupational stress, job satisfaction, work engagement, work productivity. Also, in our research, we included all employees, regardless of their parenting. Therefore, for further research, we recommend analysing the differences in constructs between employees who have children 
and those who do not have them (employees who have schooled children at home and those who have not). For further research, we suggest the examination of these four constructs in different countries to compare the results. We are researchers from two different countries (Slovenia and Croatia). Therefore, for further research, we propose analysing the same constructs in Croatia and examining the differences among Croatian and Slovenian employees in occupational stress, job satisfaction, work engagement, and work productivity during COVID-19. So, we propose to compare the results with these constructs in Slovenia and Croatia. In July 2021, the Croatian government announced that only those private organisations that vaccinated their employees would receive state financial support due to Covid-19. This caused dissatisfaction among many private entrepreneurs in the Republic of Croatia who are already under stress due to reduced economic activity in the period of lockdown. It is necessary to investigate further the impact of COVID-19 on the entry of the Republic of Croatia into the Eurozone, i.e., whether COVID-19 will disrupt the adoption of the Euro currency and how this entry will affect the job satisfaction of managers and employers as well as employees. Also, possibilities for further research include studies relating to examining differences in other constructs (for example, organisation climate, leadership, employee relations, work motivation) before the COVID-19 pandemic and during COVID-19. Also, possibilities for further research include studies relating to examining these constructs in Slovenian and Croatian organisations.

Author Contributions: Introduction, M.R. (Maja Rožman), T.Š.; A.P.; M.R. (Mladen Rajko); literature review and hypotheses, M.R. (Maja Rožman), T.Š.; A.P.; M.R. (Mladen Rajko); methodology: M.R. (Maja Rožman), T.Š.; A.P.; M.R. (Mladen Rajko); results: M.R. (Maja Rožman), T.Š.; A.P.; M.R. (Mladen Rajko); discussion: M.R. (Maja Rožman), T.Š.; A.P.; M.R. (Mladen Rajko); writing—original draft preparation, M.R. (Maja Rožman), T.Š.; A.P.; M.R. (Mladen Rajko); writing-review and editing, M.R. (Maja Rožman), T.Š.; A.P.; M.R. (Mladen Rajko). All authors have read and agreed to the published version of the manuscript.

Funding: This work has been financially supported by the University of Zadar (project number IP.01.2021.14), the Slovenian Research Agency (research core funding No. P5-0023, "Entrepreneurship for Innovative Society"), and the Erasmus+ programme (grant No. 2019-1-PL01-KA203-065050 "Economics of Sustainability").

Institutional Review Board Statement: Not applicable.

Informed Consent Statement: Not applicable.

Data Availability Statement: Not applicable.

Conflicts of Interest: The authors declare no conflict of interest.

\section{References}

1. Pedraza, P.; Guzi, M.; Tijdens, K. Life Dissatisfaction and Anxiety in COVID-19 pandemic. 2020. Available online: https: / / op.europa.eu/en/publication-detail/- / publication/d80755f6-aac5-11ea-bb7a-01aa75ed71a1/language-en (accessed on 11 April 2021).

2. Agrawal, A.; De Smet, A.; Lacroix, S.; Reich, A. To Emerge Stronger from the COVID-19 Crisis, Companies Should Start Reskilling Their Workforces Now. 2020. Available online: https://www.mckinsey.com/business-functions/organization/our-insights/to-emergestronger-from-the-COVID-19-crisis-companies-should-start-reskilling-their-workforces-now (accessed on 11 April 2021).

3. Madero Gómez, S.; Ortiz Mendoza, O.E.; Ramírez, J.; Olivas-Luján, M.R. Stress and myths related to the COVID-19 pandemic's effects on remote work. J. Manag. Res. 2020, 18, 401-420.

4. Brammer, S.; Brannicki, L.; Linnenluecke, M. COVID-19, societalization and the future of business in society. Acad. Manag. Perspect. 2020, 34, 1-38. [CrossRef]

5. Jamal, M.T.; Anwar, I.; Khan, N.A.; Saleem, I. Work during COVID-19: Assessing the influence of job demands and resources on practical and psychological outcomes for employees. Asia-Pac. J. Bus. Adm. 2021, 13, 1757-4323.

6. Lateef, F. Face to face with coronavirus disease 19: Maintaining motivation, psychological safety, and wellness. J. Emerge Trauma Shock. 2020, 13, 116-123. [CrossRef]

7. Toscano, F.; Zappalà, S. Social Isolation and Stress as Predictors of Productivity Perception and Remote Work Satisfaction during the COVID-19 Pandemic: The Role of Concern about the Virus in a Moderated Double Mediation. Sustainability 2020, $12,9804$. [CrossRef] 
8. Allen, T.D.; Golden, T.D.; Shockley, K.M. How effective is telecommuting? Assessing the status of our scientific findings. Psychol. Sci. Public Interest. 2015, 16, 40-68. [CrossRef]

9. Lee, H. Changes in workplace practices during the COVID-19 pandemic: The roles of emotion, psychological safety and organisation support. J. Organ. Eff. People Perform. 2021, 8, 2051-6614.

10. Castro-de-Araujo, L.F.S.; Machado, D.B. Impact of COVID-19 on mental health in a low and middle-income country. Ciência Saúde Coletiva. 2020, 25, 2457-2460. [CrossRef] [PubMed]

11. Singh, S. Workplace Stress and Anxiety After COVID-19. 2020. Available online: https://www.business.com/articles/workplacestress-anxiety-COVID-19/ (accessed on 14 May 2021).

12. Madell, R. Pros and Cons of Working from Home. 2019. Available online: https://money.usnews.com/money/blogs/outsidevoices-careers/articles/pros-and-cons-ofworking-from-home (accessed on 14 May 2021).

13. Anderson, G. Psychological Stress and COVID-19: Interactions with Gut Microbiome and Circadian Rhythm in Driving Symptom Severity. 2020. Available online: https://www.researchgate.net/publication/340418206_Psychological_Stress_and_COVID-19 _Interactions_with_Gut_Microbiome_and_Circadian_Rhythm_in_Driving_Symptom_Severity (accessed on 16 May 2021).

14. Chanana, N.S. Employee engagement practices during COVID-19 lockdown. J. Public Aff. 2020, 1, 1-8. [CrossRef]

15. Khan, A.A.; Abbasi, S.O.B.H.; Waseem, R.M.; Ayaz, M.; Ijaz, M. Impact of training and development of employees on employee performance through job satisfaction: A study of telecom sector of Pakistan. Strateg. Manag. J. 2016, 7, 29-46. [CrossRef]

16. Zhang, J. The dark side of virtual office and job satisfaction. Int. J. Bus Manag. 2016, 11, 40-46. [CrossRef]

17. Susilo, D. Revealing the Effect of Work-From-Home on Job Performance during the COVID-19 Crisis: Empirical Evidence from Indonesia. J. Contemp. Issues Bus. Gov. 2020, 26, 23-40.

18. Vyas, L.; Butakhieo, N. The impact of working from home during COVID-19 on work and life domains: An exploratory study on Hong Kong. Policy Des. Pract. 2021, 4, 59-76.

19. Sahni, J. Impact of COVID-19 on Employee Behavior: Stress and Coping Mechanism during WFH (Work from Home) Among Service Industry Employees. J. Oper. Manag. 2020, 1, 35-48. [CrossRef]

20. Qiu, Y.; Chen, X.; Shi, W. Impacts of social and economic factors on the transmission of coronavirus disease 2019 (COVID-19) in China. J. Popul. Econ. 2020, 33, 1127-1172. [CrossRef]

21. Prasad, K.D.V.; Vaidyab, R.W.; Mangipudi, M.R. Effect of occupational stress and remote working on psychological well-being of employees: An empirical analysis during COVID-19 pandemic concerning information technology industry in Hyderabad. Indian J. Res. Commer. Manag. 2020, 11, 1-13.

22. Mosadeghrad, A.M. Occupational Stress and its Consequences: Implications for Health Policy and Management. Lead. Health Serv. 2014, 27, 224-239. [CrossRef]

23. George, E.; Zakkariya, K.A. Job related stress and job satisfaction: A comparative study among bank employees. J. Manag. Dev. 2015, 34, 316-329. [CrossRef]

24. Goddard, B.; Morris, B.; Atwel, M. Is COVID-19 Likely to Result in an Increase in Occupational Stress Claims? 2020. Available online: https://www.dacbeachcroft.com/es/gb/articles/2020/october/is-COVID-19-likely-to-result-in-an-increase-inoccupational-stress-claims / (accessed on 10 May 2021).

25. Kraemer, M.U.; Yang, C.H.; Gutierrez, B.; Wu, C.H.; Klein, B.; Pigott, D.M.; Du Plessis, L.; Faria, N.R.; Li, R.; Hanage, W.P.; et al. The effect of human mobility and control measures on the COVID-19 epidemic in China. Science 2020, 368, 493-497. [CrossRef]

26. Feng, Z.; Savani, K. COVID-19 created a gender gap in perceived work productivity and job satisfaction: Implications for dual-career parents working from home. Gend. Manag. 2020, 35, 719-736. [CrossRef]

27. Grose, J. Burnt Out on Home Schooling? How to Get Through the Rest of the Year. 2020. Available online: www.nytimes.com/20 20/05/13/parenting/coronavirus-remote-learning-burnout.html (accessed on 6 July 2021).

28. Haag, M. Manhattan Faces a Reckoning if Working from Home Becomes the Norm. 2020. Available online: www.nytimes.com/ 2020/05/12/nyregion/coronavirus-work-fromhome.html (accessed on 13 July 2021).

29. Millard, E.; Blackburn, S. COVID Stress Is Stifling Employee Engagement, New Study Suggests. 2020. Available online: https:/ / www.verywellmind.com/covid-stress-is-stifling-employee-engagement-5084937 (accessed on 24 July 2021).

30. Maurer, R. Remote Employees Are Working Longer Than Before. 2020. Available online: https://www.shrm.org/hr-today/ news/hr-news/pages/remote-employees-are-working-longer-than-before.aspx (accessed on 14 July 2021).

31. Kamal, R.; Panchal, N.; Garfield, R. Both Remote and On-Site Workers are Grappling with Serious Mental Health Consequences of COVID-19. 2020. Available online: https://www.kff.org/policy-watch/both-remote-and-on-site-workers-are-grapplingwith-serious-mental-health-consequences-of-COVID-19/ (accessed on 27 July 2021).

32. Garg, K.; Dar, I.A.; Mishra, M. Job satisfaction and work engagement: A study using private sector Bank managers. Adv. Dev. Hum. Resour. 2017, 20, 58-71. [CrossRef]

33. Tanveer, A.; Muhammad, S.K.; Duangkamol, T.; Siraphatthada, Y.; Phumdarab, T. Impact of employees engagement and knowledge sharing on organisational performance: Study of HR challenges in COVID-19 pandemic. Hum. Syst. Manag. 2020, 39, 589-601.

34. Hayday, S. Questions to Measure Commitment and Job Satisfaction. 2003. Available online: https://www.employment-studies. co.uk/system/files/resources/files/mp19.pdf (accessed on 9 March 2021).

35. Robinson, D.; Perryman, S.; Hayday, S. The Drivers of Employee Engagement. 2004. Available online: http://www. employmentstudies.co.uk/report-summary-drivers-employee-engagement (accessed on 9 March 2021). 
36. Gallup, G. Workplace Audit-The Gallup Q12. Q12 Meta-Analysis. 2006. Available online: https://strengths.gallup.com/ private/resources/q12meta-analysis_flyer_gen_08\%2008_bp.pdf (accessed on 10 March 2021).

37. Putri, N.T.; Yusof, S.M.; Hasan, A.; Darma, H.S. A structural equation model for evaluating the relationship between total quality management and employees' productivity. Int. J. Qual. Reliab. Manag. 2017, 34, 1138-1151. [CrossRef]

38. Tabachnick, B.G.; Fidell, L.S. Using Multivariate Statistics (6th Edition); Pearson Education: Boston, MA, USA, 2013.

39. Hair, J.F.; Hult, G.T.M.; Ringle, C.M.; Sarstedt, M. A Primer on Partial Least Squares Structural Equation Modelling (PLS-SEM); Sage: Thousand Oaks, CA, USA, 2016.

40. Chronbach, L.J. Coefficient alpha and the internal structure of tests. Psychometrika 1951, 16, 297-334. [CrossRef]

41. Fornell, C.; Larcker, D.F. Evaluating structural equation models with unobservable variables and measurement error. Int. J. Mark. Res. 1981, 18, 39-50.

42. Henseler, J.; Ringle, C.M.; Sarstedt, M. A new criterion for assessing discriminant validity in variance-based structural equation modelling. Acad. Mark. Sci. Rev. 2015, 43, 115-135. [CrossRef]

43. Garson, G.D. Partial Least Squares: Regression E Structural Equation Models. Garson and Statistical Associates; Publishing: Asheboro, NC, USA, 2016.

44. Churchill, G.A.; Brown, T.J. Basic Marketing Research; Thomson: Mason, OH, USA, 2004.

45. Kock, N. Advantages of nonlinear over segmentation analyses in path models. Int. J. Collab. Enterp. 2016, 12, 1-6. [CrossRef]

46. Chin, W.W. Issues and Opinion on Structural Equation Modelling. MIS Q. 1998, 22, 1-10.

47. Henseler, J.; Dijkstra, T.K.; Sarstedt, M.; Ringle, C.M.; Diamantopoulos, A.; Straub, D.W.; Ketchen, D.J.; Hair, J.F.; Hult, G.T.M.; Calantone, R.J. Common Beliefs and Reality about Partial Least Squares: Comments on Rönkkö and Evermann. Organ. Res. Methods. 2014, 17, 182-209. [CrossRef]

48. Hu, L.; Bentler, P.M. Fit Indices in Covariance Structure Modelling: Sensitivity to Underparameterized Model Misspecification. Psychol. Methods. 1998, 3, 424-453. [CrossRef]

49. Byrne, B.M. Structural Equation Modelling with EQS and EQS/Windows; Sage Publications: Thousand Oaks, CA, USA, 1994.

50. Liguori, E.; Pittz, T.G. Strategies for small business: Surviving and thriving in the era of COVID-19. J. Small Bus. Manag. 2020, 1, 106-110. [CrossRef]

51. Gavidia, M. How Has COVID-19 Affected Mental Health, Severity of Stress Among Employees? 2020. Available online: https:/ / www.ajmc.com/newsroom/how-has-covid19-affected-mental-health-severity-of-stress-among-employees (accessed on 28 July 2021).

52. Ginger. 2020. Available online: https://www.businesswire.com/news/home/20200409005169/en/New-Data-From-GingerShows-Nearly-70-Percent-of-Workers-Feel-More-Stressed-During-COVID-19-Than-at-Any-Other-Point-in-Their-EntireProfessional-Career (accessed on 2 July 2021).

53. Kumar, P.; Kumar, N.; Aggarwal, P.; Yeap, J.A.L. Working in lockdown: The relationship between COVID-19 induced work stressors, job performance, distress, and life satisfaction. Curr. Psychol. 2021, 1-16. [CrossRef]

54. Abbas, A.M.; Zhiqiang, L. COVID-19, mental wellbeing and work engagement. Int. J. Res. Bus. Soc. Sci. $2020,9,356-365$.

55. Despinur, D.; Anis, E.; Hamidah, A. The Engagement and Working Satisfaction of Millennial Lecturers during the COVID-19 Pandemic: Differences in Gender Identity Perspectives. Syst. Rev. Pharm. 2020, 11, 438-445.

56. Gupta, B. Challenges for work-life balance during COVID-19 induced nationwide lockdown: Exploring gender difference in emotional exhaustion in the Indian setting. Gend. Manag. 2020, 35, 705-718.

57. COVID-19: Protecting People and Societies, OECD. 2020. Available online: https://www.oecd.org/inclusive-growth/resources/ COVID-19-Protecting-people-and-societies.pdf (accessed on 3 July 2021).

58. Forthcoming OECD Policy Brief: Women at the Core of the Fight against COVID-19, OECD. 2020. Available online: https: / / www.oecd.org/coronavirus / policy-responses/women-at-the-core-of-the-fight-against-COVID-19-crisis-553a8269/ (accessed on 3 July 2021). 